\title{
MUITA FÉ, MUITAS CRENÇAS: OS ESPÍRITOS DO BRASIL SÃO
}

\author{
Ricardo Oliveira de Freitas ${ }^{*}$
}

Título: Híbridos: os espíritos do Brasil

Direção: Vincent Moon e Priscilla Telmon

Duração: 85 min.

Ano: 2017.

Produção: Brasil, França.

* Doutor em Comunicação pela Universidade Federal do Rio de Janeiro, Brasil. Professor Colaborador da Universidade do Estado da Bahia, Brasil.

E-mail: ricofrei@gmail.com.

$H^{a}$ -ibridos, os espíritos do Brasil é um documentário experimental, de cunho etnográfico, como veremos adiante, que se compromete a revelar, desde o título, as múltiplas e diversas formas de religiosidades praticadas no Brasil.

Dirigido por Vincent Moon e Priscilla Telmon, o acerto do filme reside no fato de que, ao relacionar o hibridismo à pluralidade de expressões religiosas vistas no Brasil, os autores acabam revelando que, mesmo nas suas especificidades e particularidades, cada uma dessas expressões pode conter elementos muito familiares à uma outra ou a muitas outras expressões.

É essa, certamente, a motivação para a escolha do título, que, apesar de ser expressão cara e pouco simpática à Antropologia, junto com o conceito de sincretismo, tem sido tema recorrente nas muitas interpretações do Brasil e da sua cultura.

O subtítulo, entretanto, é mais esclarecedor, já que revelas os muitos espíritos do Brasil e dos brasileiros.

O hibridismo, nesse sentido, residiria na tradução da religiosidade brasileira, sobretudo, a religiosidade popular brasileira, como resultante de uma "amálgama sincrética" (para abusar de termos tão "provocadores" para os estudos de cultura e religião), que congrega os mais diversos traços das mais distintas expressões religiosas. Um caldeirão de espiritualidades. Exemplo disso, pode ser visto nas múltiplas manifestações religiosas de matriz africana praticadas no Brasil, que não são, objetivamente, africanas, mas, africanas no Brasil ou, para ser menos redundante, afro-brasileiras.

Com uma hora e vinte e cinco minutos de duração, a narrativa do filme é conduzida por uma câmera volante e movediça, que, mesmo quando age lentamente, vai adentrando os mais diversos universos religiosos, a fim de revelar não propriamente a religião, mas, tão somente, a participação religiosa, o momento em que nós brasileiros das mais diversas origens de classe, de raça, de etnia e de regionalismos exercitamos nossa fé e alimentamos nossa espiritualidade.

Não há diálogos no filme. Os únicos áudios ali presentes dizem respeito aos sons do ambiente - ao barulho da floresta, aos cânticos entoados, às músicas tocadas, às conversações com o divino. Não há, portanto, as recorrentes entrevistas e comentários (em off ou como registros de falas) que, normalmente, constroem os documentários, sobretudo os de cunho etnográfico. O texto, aqui, é propriamente a imagem. Tudo isso dá um tom experimental ao documentário, mesmo que possa ser classificado dentro da categoria documentário etnográfico. É etnografia, pois adentra universos desconhecidos, desvela estranhamentos, a fim de registrar, de modo inovador, mas, não menos descritivo, tanto a cultura material como a cultura simbólica dos grupos retratados. Mas, também é experimental, já que abole a narrativa clássica e óbvia, optando por um projeto audiovisual que muito se aproxima do proposto por Hubert Fichte com sua etnopoesia ${ }^{1}$.

Em Híbridos, a etnografia é construída com base nas imagens, nas rezas e conversas com o divino, pura e simplesmente. O interesse do filme é captar o momento em que nós, reles mortais,

\footnotetext{
FICHTE, Huber. Etnopoesia: antropologia poética das religiões afroamericanas. São Paulo: Editora Brasiliense, 1987.
} 
habitantes desse mundo cão de meu deus, daqui, do plano do ordinário, nos relacionamos com o mundo extraordinário. Os povos da floresta fazem isso muito bem, como bem retrata o filme. Mas, Híbridos também mostra que o homem da cidade, ocupante da complexa realidade urbana, não fica atrás. Os terreiros e igrejas retratadas nos grandes centros como Rio e São Paulo são referências em termos de promoção das religiosidades em sociedades ditas complexas. Me lembro, por exemplo, do terreiro de candomblé comandado pela ialorixá Omindarewá, francesa e mãe de santo radicada no Rio; e do terreiro de Umbaidame, comandado pela Mãe Baixinha, maranhense e líder espiritual radicada no Rio. As duas lideranças religiosas, nesse sentido, são bastante representativas do que, aqui, os diretores chamam de Hibridos.

Ao se propor registrar o invisível, isto é, as relações do humano com a espiritualidade, o documentário viaja pelas muitas musicalidades que promovem a ligação entre $\mathrm{o}$ mundo ordinário e o mundo extraordinário, o mundo visível e o mundo invisível, a realidade objetiva e o mundo subjetivo. Por isso, Híbridos também é importante registro de musicalidades e um excelente acervo de materiais enriquecedores para pesquisas com base na etnomusicologia.

O documentário viaja pelas mais diversas regiões do país e, nesse sentido, pelas mais distintas formas e modos de religiosidades (populares) brasileiras. Mesmo quando apresenta expressões de fé em ambientes profanos, essas não deixam de ser menos sagradas, já que envolvem ritualísticas de purificação e de comunicação com o divino e o extraordinário, a fim de que o evento ritual, religioso ou não, transcorra sem problemas. Esse, o caso do Bumba Meu Boi, no São João maranhense, ou do Maracatu, no carnaval pernambucano.

O documentário retrata, ainda, a Festa de Iemanjá, em Salvador; o Réveillon e a devoção à Iemanjá no Rio de Janeiro; o Feitio do Santo Daime; um ritual de cura no Terecô maranhense; os passes num centro espírita kardecista; um ritual tântrico; o jogo de búzios; um ritual neopentecostal no Monte Escada de Jacó, situado num subúrbio do Rio de Janeiro; uma visitação de Congado à uma igreja secular nas Minas
Gerais; um festa de Xambá pernambucano e, de modo esplêndido e pouco familiar para nosotros, brasileiros urbanos, os rituais mágicos feitos pelos povos da floresta; nesse caso, três populações indígenas situadas no Mato Grosso e no Acre. São todas manifestações de fé e de espiritualidade, que envolvem rituais mágicos e religiosos, a fim de estabelecer comunicação entre os planos ordinário e extraordinário - essa a ideia de religare, de onde provém o sentido de religião.

O filme é também um conjunto de belíssimos registros de imagens, coloridas, porém, serenas, que volta e meia provocam algum tipo de emoção no espectador. A força das imagens, nesse caso, é fortalecida pela força das manifestações de fé (como no espetacular Círio de Nazaré, em Belém do Pará), ainda que o branco das vestimentas dos fiéis prevaleça em muitas das manifestações retratadas. A trilha sonora e os resíduos e fragmentos de áudio também são importantes elementos para provocar emoção no espectador, no momento em que alimentam o sentimento de participação nessa ou naquela outra manifestação religiosa.

O filme, que teve lançamento mundial no final de 2017, é resultado de um projeto de quase seis anos, que, além do documentário, propriamente, reuniu um tanto de registros de vídeos e imagens num belo portal na Internet ${ }^{2}$.

Híbridos faz importante homenagem ao Brasil e aos brasileiros, aos nossos antepassados e às nossas ancestralidades, ao lembrar ao mundo que o Brasil, parafraseando Félix Guattari ${ }^{3}$, é um grande laboratório da pós-modernidade, já que reúne as mais diversas expressões de fé e manifestações religiosas, que congregam tradição e modernidade, campo e cidade, rural e urbano, colocando o Brasil entre as nações mais religiosas do mundo.

Por fim, Híbridos também presta importante serviço ao mostrar para o mundo e para os brasileiros o que essas expressões de fé e essas manifestações religiosas têm em comum, o que aproxima essas muitas espiritualidades. Num momento em que tanto se debate a aceitação da diferença, o reconhecimento da diversidade e o combate à intolerância religiosa, o filme é material para ser devidamente reproduzido e assistido.

Artigo recebido em I8/02/20I8 e aceito para publicação em I9/02/20।8

2 Disponível em: <http://hibridos.cc/po/>. Acesso em: 15 de fevereiro de 2018.

3 GUATTARI, Félix. (1999), “Da produção de subjetividade”. In: A. Parente (ed.). Imagem Máquina. Rio de Janeiro: Editora 34. 3ª ed. 